\title{
BUDAYA KERJA ISLAMI GURU-GURU SDN KOTA SOLOK DALAM MENINGKATKAN MUTU HASIL BELAJAR
}

\author{
Yemfimer Rahmi \\ Program Pascasarjana Sekolah Tinggi Agama Islam Negeri (STAIN) Batusangkar \\ J In. Sudiman No. 137 STAIN Batusangkar, 075271150 \\ E-mail: yemfimer_rahmi@yahoo.com \\ $+20$
}

\begin{abstract}
Work Culture Islamic Teachers of SDN Solok In Improving the Quality of Learning Outcomes. The study was conducted using a qualitative research approach with the types of qualitative research focus is to describe, analyze and interpret cultural groups. SDN object of this paper is ranked by the Solok, 06 Cape Nails SDN, SDN 16 and SDN Nan Balimo 15 Soil Salts, owns the speci schools provide educational services using principles of sharia.

From the research that has been done, the Data Showed that at SDN 06 and SDN Tanjung Paku 15 Nan culture Balimo implementation work has been going well and is supported by the parents, while at SDN 16 Soil Salts implementation work culture has also been applied by the teacher but not yet Implemented perfectly Because parental background factors and are not supported by the parents.

From the findings of the research, educational services become very important to the school as education. With services unit thus spake not only the nature of educational services related to meeting the needs of infrastructure, equipment and tools paced learning luxurious and sophisticated, but much needed school climate and environment / learning conducive, safe, and fun.
\end{abstract}

Kata Kunci: Budaya Kerja, guru-guru, mutu hasil belajar

\section{PENDAHULUAN}

Pendidikan yang diyakini sebagai salah satu upaya dalam rangka meningkatkan kualitas hidup manusia ini, pada intinya bertujuan untuk memanusiakan manusia, mendewasakan, serta merubah perilaku, serta meningkatkan kualitas menjadi lebih baik. Pada kenyataannya, pendidikan bukanlah suatu upaya yang sederhana, melainkan sebagai suatu sistem yang didalamnya mengandung elemen-elemen yang beraneka ragam dan saling berkaitan serta kegiatankegiatan yang dinamis dan penuh tantangan. Pendidikan tidaklah statis melainkan akan selalu berubah seiring dengan perubahan dan perkembangan jaman. Itulah sebabnya, pendidikan senantiasa memerlukan upaya perbaikan dan peningkatan sejalan dengan semakin tingginya kebutuhan dan tuntutan 
kehidupan masyarakat. Dan ketika kita berbicara tentang perbaikan dan peningkatan pendidikan, maka sekolah sebagai sentral dan wadah pendidikan adalah salah satu elemen penting yang harus mendapatkan perhatian secara lebih serius dan bersungguh-sungguh (Nanang Fattah, 2003:1)

Budaya pendidikan Islam harus mampu menyiapkan sumber daya manusia yang tidak sekedar sebagai penerima arus informasi global, tetapi juga harus memberi bekal kepada mereka agar dapat mengolah, menyesuaikan dan mengembangkan segala hal yang diterima melalui arus informasi itu, yakni manusia yang kreatif dan produktif. Karena itu, budaya sekolah diharapkan menjadi ujung tombak keberhasilan lembaga dalam mengadakan proses-proses pendidikan untuk mencapai tujuan bersama dalam dunia pendidikan Islam yaitu muslim yang ber-IPTEK dan ber-IMTAQ. Karena tujuan khusus pendidikan Islam; (1) Mendidik individu yang shaleh dengan memperhatikan segenap dimensi perkembangannya: rohaniah, emosional, sosial, intelektual, dan fisik (2) Mendidik anggota kelompok sosial yang shaleh, baik dalam keluarga maupun masyarakat muslim (3) Mendidik individu yang shaleh bagi masyarakat. Disinilah diperlukan satu bentuk pengelolaan budaya sekolah yang sesuai dengan tuntunan ajaran Islam, yaitu manajemen budaya sekolah Islami. Sedangkan, strategi atau pendekatan yang dipakai dalam penerapan budaya Islami ini ditekankan pada suatu model seruan atau ajakan yang bijaksana dan pembentukan sikap manusia (afektif) (Nanang Fattah, 2003:2).
Budaya kerja menurut perspektif Islam termasuk ruang lingkup ibadah. Ibadah di dalam Islam terdiri dari ibadah Am dan ibadah Khas. Ibadah khas berupa ibadah yang sudah ditetapkan tata caranya secara lengkap. Prinsip ibadah ini adalah semuanya dilarang kecuali yang dibolehkan. Ibadah ini berupa rukun Islam. Ibadah Am berupa ibadah yang tidak ditetapkan tata caranya. Prinsip ini adalah semuanya dibolehkan kecuali yang dilarang. Ibadah ini berupa muamalah (Ahlami, 26 oktober, 22.03).

Berdasarkan penelitian awal yang penulis lakukan terhadap beberapa SDN di Kota Solok ternyata pemahaman guru terhadap budaya kerja Islami yaitu nilai Islam masih kurang sehingga kurang terciptanya budaya kerja produktif. Begitu juga hasil belajar siswa pada beberapa SDN Kota Solok yang penulis kunjungi ternyata hasil belajar siswa yang masih kurang dengan nilai-nilai Islam. Dari uraian diatas dapat ditarik kesimpulan bahwa untuk membangun mutu hasil belajar di SDN Kota Solok sudah di dukung oleh budaya kerja Islami, sehubungan dengan hal tersebut perlu dilakukan penelitian lebih mendalam tentang: "Budaya Kerja Islami guru-Guru SDN Kota Solok Dalam Meningkatkan Mutu Hasil Belajar". Adapun yang menjadi focus penelitian ini tentang budaya kerja islami guru-guru SDN Kota Solok dalam meningkatkan mutu hasil belajar. Sedangkan yang menjadi sub focus penelitian ini adalah bagaimana budaya kerja islami guru-guru SDN Koto Solok dalam meningkatkan mutu hasil belajar. Berdasarkan fokus dan sub fokus penelitian maka dalam penelitian ini rumusan masalahnya sebagai berikut: 1) Bagaimanakah 
budaya kerja islami pada SDN Kota Solok?. 2) Bagaimanakah Budaya kerja islami dalam meningkatkan mutu hasil belajar SDN Kota Solok?

\section{PEMBAHASAN}

Budaya kerja Islam berarti mengaktualisasikan seluruh potensi iman, pikir, dan zikir, serta keilmuan kita untuk memberikan nilai kebahagiaan. Inti atau sumber inspirasi budaya Islam adalah $\mathrm{Al}$-qur" an dan sunnah Rasululllah SAW, yang diikat dalam satu kata, yaitu akhlak. Menurut Lukman Hakim bahwa karakteristik budaya kerja islami adalah sebagai berikut: a) Bekerja merupakan "ibadah".b) Bekerja dengan azas manfaat dan maslahat. c) Bekerja dengan mengoptimalkan kemampuan. d) Bekerja dengan penuh keyakinan dan optimistic. e) Bekerja dengan mensyaratkan adanya sikap tawazun (keberimbangan). f) bekerja dengan memperhatikan unsur kehalalan dan menghindari unsur haram (yang dilarang syariah).

Menurut didin hafidhuddin (2003) budaya kerja pada organisasi bernuansa islam haruslah memilliki nilai-nilai yang mencerminkan akhlak islami, antara lain: Indikator organisasi islam dapat dilihat dari nilai akhlak (perilaku) islami sebagai berikut: 1) Siddiq (Jujur). 2) Istiqamah (Konsisten). 3) Fathanah (Memahami). 4) Amanah (Bertanggungjawab). 5) Tabligh (Memberikan keteladanan).

Aspek budaya kerja adalah nilai yang menjadi pedoman sumber daya manusia untuk menghadapi permasalahan eksternal dan usaha penyesuaian integrasi ke dalam perusahaan, sehingga anggota organisasi mampu memahami nilai-nilai yang ada dan bagaimana mereka harus bertindak atau berperilaku. Pada penelitian ini yang menjadi objek merupakan sekolah, maka yang menjadi aspek budaya kerja islami adalah pelayanan unggul atau prima (service execellent), dimana para majelis guru selain tugasnya sebagai mengajar juga melayani para siswa, orang tua dan wali siswa serta masyarakat sekitarnya. Pelayanan unggul atau prima (service execellent) adalah dua kata berasal dari bahasa inggeris service dan excellent. Service artinya jasa, pelayanan, tugas dan excelent artinya unggul, ulung, baik sekali, dengan demikian dalam perspektif ini pelayanan yang sempurna merupakan salah satu nilai jual yang penting bagi sebuah industri jasa. Sebuah pelayanan dikatakan sempurna apabila dampak yang terjadi pada siswa adalah loyalitas yang sangat tinggi. Sehingga dalam kasus pendidikan sekolah, siswa tidak akan ragu-ragu lagi untuk mengikuti pendidikan di sekolah. Bahkan, siswa akan dengan sendirinya memasarkan sekolah tersebut dengan sukarela dikarenakan sudah sangat nyaman dan di untungkan dengan adanya pelayanan yang sempurna tersebut.

Secara umum landasan utama pelayanan prima ialah menolong orang lain. Dalam islam pelayanan prima tidak hanya sekedar menolong orang lain, akan tetapi juga sebagai ibadah kepada Allah SWT. Ketika pelayanan prima benar-benar diaplikasikan baik dalam kehidupan bermasyarkat atau dunia pendidikan maka efek baik juga akan dirasakan, diantaranya : kepercayaan (trust), loyalitas (loyality), confident, marketing mulut 
(mouth marketing), profit, perkembangan pendidikan akan meningkat (growth), selain itu silaturahmi akan terjaga, hidup menjadi berkah, persatuan umat akan terjaga, dan yang pasti surga akan didapat.

Adapun indikator palayanan unggul atau prima (service excellent) sebagai berikut:

\section{1) Siddiq (Jujur/Tangibles).}

Siddiq atau jujur (Tangibles) yaitu pelayanan dalam hal fisik, perlengkapan dan penampilan pegawai dan sarana komunikasi. Bukti fisik (tangible) menyangkut fasilitas fisik organisasi yang nampak, peralatan yang digunakan, serta bahan komunikasi yang digunakan oleh organisasi jasa. Bukti fisik merupakan tampilan fisik yang akan menunjukkan identitas organisasi sekaligus faktor pendorong munculnya persepsi awal pelanggan terhadap suatu organisasi jasa. Ketidakmampuan organisasi dalam menampilkan bukti fisiknya dengan baik, akan melemahkan citra serta dapat menciptakan persepsi negatif pada pelanggan. Islam mewajibkan untuk menolong seseorang dalam keadaan darurat tanpa melihat kondisi keuangan dan kemampuan membayar biaya tindakan medis. Seperti dalam ayat al-qur'an surat 'Abasa yang menegaskan:

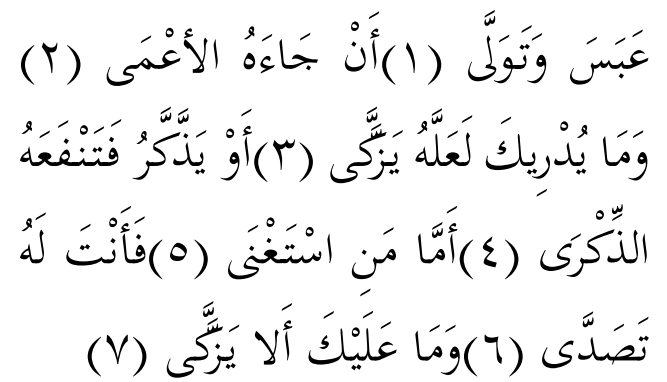

Dia (Muhammad) bermuka masam dan berpaling, karena telah datang seorang buta kepadanya tahukah kamu barangkali ia ingin membersibkan dirinya (dari dosa), atau Dia (ingin) mendapatkan pengajaran, lalu pengajaran itu memberi manfaat kepadanya? Adapun orang yang merasa dirinya serba cukup, Maka kamu melayaninya.Padahal tidak ada (celaan) atasmu kalau Dia tidak membersibkan diri (beriman).

Thabathaba'i berpendapat bahwa surah ini merupakan kecaman kepada siapa yang memberi perhatian kepada orang-orang kaya yang bermewah-mewah dengan mengabaikan orang-orang lemah dan miskin dari kaum beriman. Thabathaba'i mengemukakan riwayat yang berbeda dengan riwayat populer di kalangan kelompok Ahl as-Sunnah yang mengatakan bahwa ayat ini turun sebagai teguran kepada Nabi Muhammad SAW yang bermuka masam terhadap 'Abdullah Ibn Ummi Maktum yang tunanetra.

\section{2) Istiqamah (Konsisten atau Empathy)}

Perhatian (Empathy) yaitu Perusahaan/ pegawai sangat perhatian kepada pelanggan dan memahami kebutuhan nasabah (termasuk ego dan aktualisasi) atau kemudahan dalam melakukan hubungan komunikasi yang baik dan memahami kebutuhan pelanggan. Empathy menyangkut kepedulian organisasi terhadap maksud dan kebutuhan pelanggan, komunikasi yang baik dengan pelanggan, dan perhatian khusus terhadap mereka. Empathy dapat mendekatkan hubungan antara organisasi dan pelanggannya sehingga membentuk pola interaksi positif yang menguntukan kedua belah pihak. Sebuah organisasi jasa syariah harus senatiasa memberikan perhatian khusus terhadap masing-masing pelanggannya yang ditunjukkan dengan sikap 
komunikatif yang diiringi kepahaman tentang kebutuhan pelanggan. Hal ini merupakan wujud kepatuhan penyedia jasa terhadap perintah Allah Táalā untuk selalu peduli terhadap kondisi dan kebutuhan orang lain, sebagaimana Nabi Muhammad SAW bersabda:

\section{'barang siapa yang mencukupi kebutuhan saudarnya, niscaya allah akan memenuhi kebutuhannya, dan barang siapa yang melepaskan satu kesusahan yang dialami oleh seorang muslim, maka allah akan meng- hindarkannya dari satu kesusahan di hari kiamat. "(HR.muslim)}

\section{3) Fathanah (Layanan Konsisten atau Reliabilty)}

Fathanah (Reliability) yaitu layanan konsisten sesuai janji dan dapat diandalkan kualitasnya atau kemampuan untuk memberikan jasa dengan segera dan memuaskan. Reliability (keandalan) merupakan kemampuan penyampaian kinerja yang telah dijanjikan kepada pelanggan secara handal dan akurat, artinya pelanggan dapat melihat dan memberikan kesan spontan bahwa kinerja jasa yang diberikan oleh organisasi terjamin, tepat, dan terasa memberikan kemudahan bagi pelanggan. Hal ini dapat dilihat dari sistematika pelayanan dan bentuk pelayanan. Kehandalan merupakan inti dari kualitas jasa, karena pelanggan menilainya berdasarkan pengalaman dalam menggunakan jasa tersebut (Lovelock dan Wright, 2007: 99). Oleh kerena itu, sebuah organisasi jasa syariah harus mampu menyediakan jasa yang telah dipublikasikannya secara handal dan akurat.

\section{4) Amalan (bertanggung jawa atau Assurance)}

Amanah atau Jaminan (Assurance) yaitu kemampuan perusahaan dan frontliners dalam menanamkan rasa percaya dan keyakinan pada nasabah (keramahan, kompetensi, kredibilitas dan kenyamanan) atau memiliki sifat yang dapat dihandalkan dan dipercaya. Assurance (jaminan) adalah pengetahuan yang luas karyawan terhadap produk, kemahiran dalam menyampaikan jasa, sikap ramah/sopan, serta kemampuan mereka untuk menumbuhkan kepercayaan pelanggan. Pengetahuan dan kemahiran atas suatu produk hanya akan diperoleh dari sebuah proses belajar yang tekun dan bersungguh-sungguh. Islam memerintahkan agar setiap muslim senantiasa belajar dengan tekun dan terus meningkatkan kemampuan dirinya. Hal ini berdasarkan firman Allah Tảalā tentang keutamaan orang yang berilmu, sebagaimana dalam Qs. AlBaqarah [2]:283, yakni:

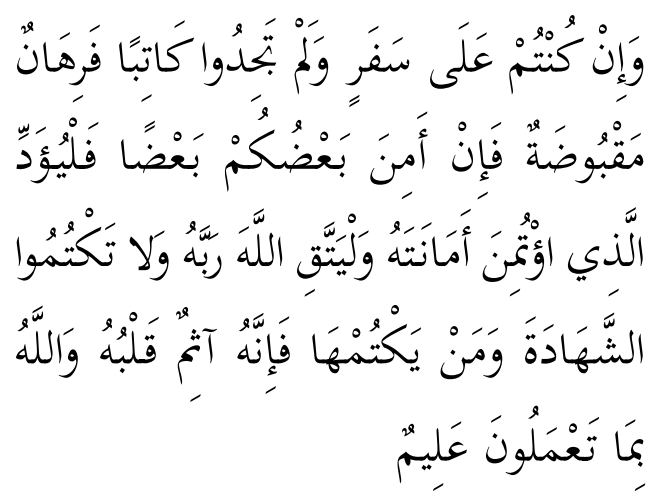

Jika kamu dalam perjalanan (dan bermu'amalah tidak secara tunai) sedang kamu tidak memperoleh seorang penulis, Maka hendaklah ada barang tanggungan yang dipegang (oleh yang berpiutang). akan tetapi jika sebagian kamu mempercayai sebagian yang lain, Maka hendaklah yang dipercayai itu menunaikan amanatnya 
(hutangnya) dan hendaklah ia bertakwa kepada Allah Tuhannya; dan janganlah kamu (para saksi) Menyembunyikan persaksian. dan Barangsiapa yang menyembunyikannya, Maka Sesungguhnya ia adalah orang yang berdosa hatinya; dan Allah Maha mengetahui apa yang kamu kerjakan.

Rasulullah Şalla'-Lahu alaibi wa Sallam memberikan motivasi kepada ummatnya agar bersunguh-sungguh dalam meningkatkan kapasitas dirinya melalui menuntut ilmu. Kesunguhan dalam menuntut ilmu tersebut akan dibalas oleh Allah Ta'ala dengan kemudahan menuju surga-Nya. Peningkatan pengetahuan personal sangatlah penting bagi organisasi jasa. Karyawan yang memiliki pengetahuan luas terhadap sebuah jasa, akan mampu berbicara lebih luas tentang jasa tersebut dan dapat menyampaikan jasa lebih baik kepada pelanggan. Proses penyampaian jasa yang baik dapat meningkatkan kepercayan pelanggan terhadap organisasi, karena pelanggan akan membandingkan informasi yang dia dapat dengan pengalaman setelah menggunakan jasa. Apabila informasi yang didapat berbanding lurus dengan pengalaman, maka persepsi positif pelanggan terhadap produk jasa tersebut akan semakin bertambah, dan selanjutnyat dapat mendorong keputusan pelanggan untuk menggunakannya kembali pada masa yang akan datang. Bagian lain dari dimensi Assurance adalah sikap karyawan yang ramah dan sopan. Hal tersebut dapat menarik perhatian dan membentuk hubungan baik antara kedua belah pihak. Sikap tersebut merupakan bagian dari etika perdagangan yang harus dijalankan oleh setiap muslim. Allah Táalā juga memerintahkan kepada setiap muslim untuk mengucapkan kata-kata yang baik ketika berinteraksi dengan orang lain.

\section{5) Tabligh (Kecapatan Responsivenes)}

Kecepatan (Responsivenes) yaitu kecepatan untuk memberikan layanan terbaik berdasarkan persepsi atau kemampuan untuk memberikan jasa dengan tanggap. Responsiveness (daya tanggap) menyangkut kerelaan sumber daya organisasi untuk memberikan bantuan kepada pelanggan dan kemampuan untuk memberikan pelayanan secara cepat (responsif) dan tepat. Daya tanggap merupakan bagian dari profesionalitas. Organisasi yang profesional senantiasa berkomitmen untuk memberikan pelayanan terbaik, memperhatikan harapan dan masukan dari pelanggan serta meresponnya dengan cepat dan tepat. Jika tidak demikian, berarti manajemen organisasi tersebut telah menzalimi pelanggan. Dalam pelaksanaan suatu pekerjaan, seorang dikatakan profesional apabila dirinya bekerja sesuai dengan keahlian atau kemampuannya. Pekerjaan akan dapat dilakukan dan diselesaikan dengan baik secara cepat dan tepat apabila dilakukan oleh orang yang memiliki kemampuan sesuai dengan bidang pekerjaannya. Kepercayaan yang diberikan konsumen merupakan suatu amanat. Apabila amanat tersebut disia-siakan akan berdampak pada ketidakberhasilan dan kehancuran lembaga dalam memberikan pelayanan kepada konsumen. Untuk itu kepercayaan konsumen sebagai suatu amanat hendaknya tidak disia-siakan dengan memberikan pelayanan secara profesional melalui pegawai yang bekerja sesuai dengan 
bidangnya dan mengerjakan pekerjaannya secara cepat dan tepat, sebagaimana yang dinyatakan dalam hadis Rasulullah SAW diriwayatkan oleh Bukhari, yaitu: "apabila amanat disia-siakan, maka tunggulah kehancurannya, berkata seseorang: bagaimana caranya menyia-nyiakan amanat ya Rasulullah? Berkata Nabi: apabila diserahkan sesuatu pekerjaan kepada yang bukan ablinya, maka tunggulah kehancurannya".

Ditinjau dari sudut hokum, dipinisi pendidikan berdasarkan undang-undang RI Nomor 20 tahun 2003 tentang Sistem Pendidikan Nasional (Sisdiknas), pasal 1(1 dan 4),yaitu "pendidikan adalah usaha sadar dan terencana untuk mewujudkan suasana belajar dan proses pembelajaran agar peserta didik secara aktif mengembangkan potensi dirinya untuk memiliki kekuatan spiritual keagamaan, pengendalian diri, keperibadian, kecerdasan, akhlak mulia, serta keterampilan yang diperlukan dirinya, masyarakat, bangsa dan negara." "Peserta didik adalah anggota masyarakat yang berusaha mengambangkan potensi diri melalui proses pembelajaran yang tersedia pada jalur, jenjang, dan jenis pendidikan. Menurut Sunario seperti dikutip Usman potensi otak manusia yang digunakan untuk barpikir baru 4\% .Jadi masih 96\% dari otak manusia yang belum digunakan untuk berpikir. Mutu di bidang pendidikan meliputi mutu input, proses, output, dan outcome. Input pendidikan dinyatakan bermutu jika siap berperoses. Proses pendidikan bermutu apabila mampu menciptakan suasana yang PAKEM (Pembelajaran yang Aktif, Kreatif, dan Menyenangkan).
Husaini Usman mengemukakan 13 (tiga) belas karakteristik yang dimiliki oleh mutu pendidikan yaitu : 1) Kinerja (performa) yakni berkaitan dengan aspek fungsional sekolah meliputi : kinerja guru dalam mengajar baik dalam memberikan penjelasan meyakinkan, sehat dan rajin mengajar, dan menyiapkan bahan pelajaran lengkap, pelayanan administratif dan edukatif sekolah baik dengan kinerja yang baik setelah menjadi sekolah vaforit. 2) Waktu wajar (timelines) yakni sesuai dengan waktu yang wajar meliputi memulai dan mengakhiri pelajaran tepat waktu, waktu ulangan tepat. 3) Handal (reliability) yakni usia pelayanan bertahan lama. Meliputi pelayanan prima yang diberikan sekolah bertahan lama dari tahun ke tahun, mutu sekolah tetap bertahan dan cenderung meningkat dari tahun ke tahun. 4) Data tahan (durability) yakni tahan banting, misalnya meskipun krisis moneter, sekolah masih tetap bertahan. 5) Indah (aesteties) misalnya eksterior dan interior sekolah ditata menarik, guru membuat media-media pendidikan yang menarik. 6) Hubungan manusiawi (personal interface) yakni menunjung tinggi nilai-nilai moral dan profesionalisme. Misalnya warga sekolah saling menghormati, demokrasi, dan menghargai profesionalisme. 7) Mudah penggunaanya (easy of use) yakni sarana dan prasarana dipakai. Misalnya aturan-aturan sekolah mudah diterapkan, buku-buku perpustakaan mudah dipinjam di kembalikan tepat waktu. 8) Bentuk khusus (feature) yakni keuggulan tertentu misalnya sekolah unggul dalam hal penguasaan teknologi informasi (komputerisasi). 9) Standar 
tertentu (comformence to specification) yakniu memenuhi standar tertentu. Misalnya sekolah tetlah memenuhi standar pelayanan minimal. 10) Konsistensi (concistency) yakni keajengan, konstan dan stabil, misalnya mutu sekolah tidak menurun dari dulu hingga sekarang, warga sekolah konsisten dengan perkataanya.11) Seragam (uniformity) yakni tanpa variasi, tidak tercampur. Misalnya sekolah melaksanakan aturan, tidak pandang bulu, seragam dal berpakaian.12) Mampu melayani (serviceability) yakni mampu memberikan pelayanan prima. Misalnya sekolah menyediakan kotak saran dan saran-saran yang masuk mampu dipenuhi dengan baik sehingga pelanggan merasa puas. 13) Ketepatan (acuracy) yakni ketepatan dalam pelayanan misalnya sekolah mampu memberikan pelayanan sesuai dengan yang diinginkan pelanggan sekolah.

\section{Budaya Kerja Islami Sekolah Dasar Negeri (SDN) 06 Tanjung Paku}

Budaya kerja islami dalam rangka meningkatkan mutu hasil belajar di SDN 06 Tanjung Paku sudah berjalan dengan baik. mutu hasil belajar sangat dipengaruhi dari factor ekonomi, kerjasama orang tua dengan sekolah berjalan baik walaupun orang tua sibuk tetapi orang tua masih menghiraukan anaknya sehingga mau sekolah, setiap aturan yang dibuat ikut serta untuk menerapkannya seperti disiplin, murid belajar serius, bahkan ada anak yang tinggal jauh dari sekolah agar jangat terlambat selalu datang cepat. Membudayakan mengucapkan salam, doa sebelum/sesudah belajar, do'a. Orang tua murid puas dengan anak bersekolah di SD ini, karena perkembangan dan kemajuan anak sangat bagus.

\section{Budaya Kerja Islami Sekolah Dasar} Negeri (SDN) 16 Nan Balimo

Budaya kerja islami dalam rangka meningkatkan mutu hasil belajar di SDN 16 Nan Balimo sudah berjalan dengan baik. mutu hasil belajar sangat dipengaruhi dari factor ekonomi, kerjasama orang tua dengan sekolah berjalan baik walaupun orang tua sibuk tetapi orang tua masih menghiraukan anaknya sehingga mau sekolah, setiap aturan yang dibuat ikut serta untuk menerapkannya seperti disiplin, murid belajar serius, bahkan ada anak yang tinggal jauh dari sekolah agar jangat terlambat selalu datang cepat. Membudayakan mengucapkan salam, doa sebelum/sesudah belajar, do'a. Orang tua murid SDN 16 Nan Balimo jelas terlihat bahwa orang tua murid puas dengan anak bersekolah di SD ini, karena perkembangan dan kemajuan anak sangat bagus.

\section{Budaya Kerja Islami Sekolah Dasar Negeri (SDN) 15 Tanah Garam.}

Berdasarkan hasil wawancara peneliti dengan kepala sekolah dapat disimpulkan bahwa budaya kerja islami dalam rangka meningkatkan mutu hasil belajar di SDN 15 Tanah Garam belum berjalan dengan baik, dimana kepala sekolah sudah mengarahkan kepada guru-gurunya untuk menerapkan budaya disiplin, budaya salam dan pelaksanaan PBM 
dengan sebaik mungkin dan sesuai dengan kurikulum yang berlaku untuk dapat meningkatkan hasil belajar, tetapi kenyataannya mutu hasil belajar belum baik karena hal ini disebabikan tidak adanya dukungan dari orang tua murid dan lingkungan disekolah sehingga mengakibatkan mutu hasil belajar murid kurang bagus. Budaya kerja islami dalam rangka meningkatkan mutu hasil belajar di SDN 15 Tanah Garam belum terlaksana dengan baik. Hal ini disebabkan karena mutu hasil belajar sangat dipengaruhi dari factor ekonomi, kerjasama orang tua dengan sekolah berjalan baik oleh karena orang tua sibuk dan tidak menghiraukan anaknya sehingga anak tidak mau sekolah, setiap aturan yang dibuat tidak ikut serta untuk menerapkannya seperti disiplin, murid belajar serius, bahkan banyak anak yang sering terlambat datang cepat. Tidak membudayakan mengucapkan salam, doa sebelum/sesudah belajar, do'a. Orang tua murid SDN 15 Tanah Garam jelas terlihat bahwa orang tua murid kurang puas dengan anak bersekolah di SD ini, karena perkembangan dan kemajuan anak sangat kurang bagus hal ini disebabkan karena adanya pengaruh lingkungan dan factor keluarga yang kurang mendukung dari program-program sekolah.

Peneliti akan memaparkan/menjelaskan hasil penelitian tentang budaya kerja islami guru-guru SDN Kota Solok dalam meningkatkan mutu hasil belajar dari sudut pandang pelayanan unggul/utama (excellent service).

\section{a) Siddiq (Jujur/Tangibles)}

Melalui wawancara dengan salah satu guru SDN 06 Tanjung Paku yaitu ibu Sri Mis Iswati pada tanggal 19 Mei 2014 tentang pelayanan yang diberikan oleh guru atau sekolah kepada murid dalam pembelajaran yang mana guru telah merancang pembelajaran secara islami yaitu terungkap. Dalam proses PBM kami para guru terlebih dahulu membuat RPP yang sesuai dengan kurikulum yang berlaku pada saat ini, yang mana tujuannya adalah untuk meningkatkan mutu hasil belajar. Hal ini sejalan dengan hasil wawancara peneliti dengan murid di SDN 06 Tanjung Paku dimana mengatakan bahwa: Kami/muridmurid SDN 06 Tanjung Paku dalam proses pembelajaran menerima pelayanan yang baik dari guru-guru kami, dimana kami diberi pinjaman buku cetak dan kami merasakan sama dengan temanteman kami yang sekolahnya di luar dari SDN 06 Tanjung Paku. Berdasarkan hasil wawancara peneliti dengan Ibu Sri Mis Iswati jelas terlihat bahwa SDN 06 Tanjung Paku memberikan pelayan yang bagus kepada muridnya sehingga mengakibatkan mutu hasil belajar murid optimal.

Kalau dilihat dari hasil wawancara peneliti dengan salah seorang guru SDN $16 \mathrm{Nan}$ Balimo yaitu ibu Fitriani pada tanggal 22 Mei 2014 dimana ibu Fit menyatakan bahwa guru-guru di SDN 16 Nan Balimo selalu memberikan pelayanan yang terbaik kepada murid-muridnya dan selalu 
berupaya untuk bisa meningkatkan hasil belajar yang meningkat dari tahunketahun sehingga memungkinkan SDN 16 Nan Balimo mendapat rangking pertama UN muridnya, tetapi hal ini tidak tercapai karena pada umumnya orang tua siswa sebagai buruh dan siswanya banyak anak panti sehingga mengakibatkan banyaknya halangan dan pengaruh lingkungan serta teknologi dimana anak yang selalu diberi tugas untuk mencari jawaban di internet hal inilah yang disalah gunakan oleh muridnya. Sehingga mengakibatkan mutu hasil belajar siswa belum optimal.

Hal ini seiring dengan jawaban hasil wawancara peneliti dengan guru di SDN 15 Tanah Garam dimana guru telah memberikan pelayanan yang sebaik-baik mungkin dan telah berusaha melaksanakan PBM dan pembuatan RPP yang sesuai dengan kurikulum yang berlaku yang tujuannya adalah agar dapat mutu hasil belajar yang maksimal sesuai dengan tujuan yang telah ditetapkan. Tetapi hal ini tidak bisa terwujud karena tidak adanya dukungan dari orang tua murid, hal ini disebabkan karena factor ekonomi orang tua yang sedang. Berdasarkan hasil wawancara peneliti diperoleh bahwa anak menjawan mereka memperoleh pelayan yang baik di sekolah dan diberi pinjaman buku yang sesuai dengan kurikulum yang berlaku tetapi mereka tidak bisa belajar atau mengerjakan PR yang telah diberikan oleh guru di sekolah, hal ini disebabkan karena murid apabila telah pulang sekolah membantu orang tua seperti berjualan, mencari makanan untuk ternak dan setelah sore pulang, sehingga anak pada malam harinya sudah keletihan dan akhirnya ketiduran.

\section{b) Istiqamah (Konsisten atau Empathy)}

Hal ini merupakan wujud kepatuhan penyedia jasa terhadap perintah Allah Tảalā untuk selalu peduli terhadap kondisi dan kebutuhan orang lain, sebagaimana firman-Nya dalam Qs. An-Nahl [16] : 90, yakni :

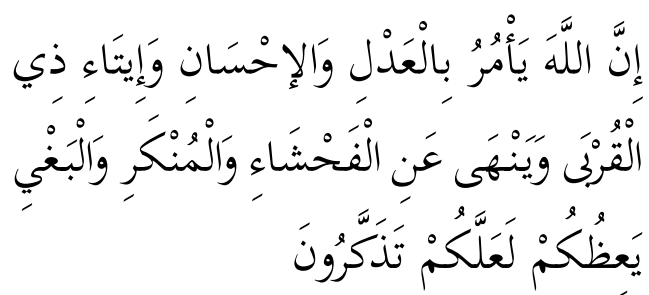

"Sesungguhnya Allah menyuruh (kamu) berlaku adil dan berbuat kebajikan, memberi kepada kaum kerabat, dan Allah melarang dari perbuatan keji, kemungkaran dan permusuhan. Dia memberi pengajaran kepadamu agar kamu dapat mengambil pelajaran."

Guru akan sedikit sulit memberikan nilai yang sebenarnya kepada peserta didik yang biasa berprestasi, sehingga nilai yang dihasilkan tetap tidak buruk. Sikap kurang profesionalismenya guru ini akaibat dorongan dari simpati yang ditunjukkan kepada peserta didiknya yang selalu berprestasi. Tetapi tidak pula semua guru memiliki sikap seperti ini, karena ada guru yang memang ingin menunjukkan kepada siapapun peserta didiknya nilai yang sebenarnya. Walaupun peserta didik tersebut adalah juara kelas tetapi ada guru yang tetap ingin menunjukkan nilai asli yang diperolehnya, agar peserta 
didik tersebut tetap memperhatikan pola belajarnya. Selain itu juga tuntutan pihak sekolah untuk bisa memahami apa yang dibutuhkan peserta didik memang harus tetap dilakukan. Supaya setiap kebutuhan peserta didik dalam upaya meningkatkan kualitasnya dapat terpenuhi.

Disiplin merupakan satu kata yang sangat mudah diucapkan, namun sulit Melalui wawancara dengan Ibu MISDA, S.Pd.SD SDN 06 Tanjung Paku, Ibu RIOLINDA,S.Pd guru SDN 16 Nan Balimo dan Ibu ELMI YANTI,J guru SDN 15 Tanah Garam menyatakan sama tentang empati guru kepada murid dalam pembelajaran yang menerapakan pada anak agar membiasakan diri untuk mengucapkan salam setiap berjumpa dengan guru atau sahabat. Berdasarkan hasil wawancara peneliti dengan Ibu MISDA, S.Pd.SD SDN 06 Tanjung Paku, Ibu RIOLINDA, S.Pd guru SDN 16 Nan Balimo dan Ibu ELMI YANTI, J guru 15 Tanah Garam terlihat bahwa murid mengikuti anjuran dari guru yang selalu mengucapkan salam kepada guru dan teman setiap berjumpa. Dapat disimpulkan bahwa budaya kerja islami di SDN 15 Tanah Garam berjalan dengan baik dimana membudayakan mengucapkan salam, doa sebelum/ sesudah belajar, doa bersama menyambut UN/US dan kebaktian, sholat zuhur berjamaah, dalam pelaksanaan PBM sikap guru dalam mengajar baik dan bagus. Guru mengajar selalu membuka pelajaran dengan membaca doa. Guru mengajar selalu membawa alat-alat media ada, ada juga murid mengikuti les sebagai tambahan belajar yang merasa kurang mengerti disekolah yang menyebabkan ingin menambah waktu belajar di lembaga pendidikan lainnya dimana dalam pelaksanaan PBM sikap guru dalam mengajar baik dan bagus. Guru mengajar selalu membuka pelajaran dengan membaca doa. guru mengajar selalu membawa alat-alat media ada, hanya saja kalau kami belajar menggunakan media serasa main-main saja. PR kadang dibuat kadang tidak, karena malas mengerjakannya. Orang tua tidak marah kalau tidak membuat PR,karena orang tua sibuk. jarak tempat tinggal dengan sekolah jauh . kadang jajan dan kadang tidak karena tidak ada uang.guru dalam memberikan nilai adil. Tentang mutu hasil belajar dimana dalam pembelajaran guru selalu menggunakan media yang ada, hanya saja kalau kami belajar menggunakan media serasa main-main saja. Guru melakukan evaluasi setelah pembelajaran.Hal ini juga didukung dari hasil wawancara peneliti dengan murid yaitu Adi Maulana Yusuf murid SDN 06 Tanjung Paku, Zulnofri murid SDN 16 Nan Balimo dan Noverman murid SDN 15 Tanah Garam yang menanyakan tentang apakah guru membimbing anda untuk memiliki karakter yang rajin beribadah (religious), yaitu terungkap setiap hari kepala sekolah, guru dan orang orang tua selalu mengarahkan saya rajin belajar dan rajin beribadah. 
c) Fathanah (Layanan Konsisten atau Reliabilty)

Reliabiliti yaitu layanan konsisten sesuai janji dan dapat diandalkan kualitasnya atau kemampuan untuk memberikan jasa dengan segera dan memuaskan. Dapat disimpulkan bahwa budaya kerja islami di SDN 06 Tanjung Paku, SDN 16 Nan Balimo dan SDN 15 Tanah Garam sudah berjalan dengan baik hal ini menunjukkan bahwa guru selalu mentaati prosedur dan instruksi secara tepat dan sangat membudayakan disiplin waktu seperti tepat waktu masuk dan pulang, disiplin dalam belajar yang menggunakan waktu seefisien mungkin dan pada hari Jumat mengadakan Kultum lebih kurang $1 / 2$ jam. Orang tua ikut serta menggerakkan anak sepenuhnya sekolah dengan cara memantau atau mensupport untuk kemajuan anak. Hanya saja untuk murid SDN 15 Tanah Garam murid kadangkadang terlambat dating kesekolah itu dikarenakan jarak sekolah dengan rumah murid jauh, kadang tidak membuat PR hal ini dikarenakan murid pulang sekolah ikut membantu orang tua dirumah sehingga anak kecapaian dan tidak sempat membuat PR.

d) Amalan (bertanggung jawa atau Assurance)

Assurance yaitu kemampuan perusahaan dan frontliners dalam menanamkan rasa percaya dan keyakinan pada nasabah (keramahan, kompetensi, kredibilitas dan kenyamanan) atau memiliki sifat yang dapat dihandalkan dan dipercaya.
Assurance (jaminan) adalah pengetahuan yang luas karyawan terhadap produk, kemahiran dalam menyampaikan jasa, sikap ramah/sopan, serta kemampuan mereka untuk menumbuhkan kepercayaan pelanggan. Pengetahuan dan kemahiran atas suatu produk hanya akan diperoleh dari sebuah proses belajar yang tekun dan bersungguh-sungguh. Perkataan yang baik (sopan) dan lemah lembut (ramah) akan membentuk pola interaksi yang berkualitas. Keberhasilan seorang dalam berinteraksi akan membawa hasil yang saling menguntungkan para pihak terkait.

e) Tabligh (Kecapatan Responsivenes)

Responsivenes yaitu kecepatan untuk memberikan layanan terbaik berdasarkan persepsi atau kemampuan untuk memberikan jasa dengan tanggap. Budaya kerja islami yaitu bertanggung jawab atas segala hal yang dikerjakan dapat berjalan dengan baik dimana dalam pelaksanaan PBM guru menugaskan PR kadang dibuat kadang tidak, karena malas mengerjakannya. Orang tua tidak marah kalau tidak membuat PR,karena orang tua sibuk. jarak tempat tinggal dengan sekolah jauh. kadang jajan dan kadang tidak karena tidak ada uang.guru dalam memberikan nilai adil. Tentang mutu hasil belajar dimana dalam pembelajaran guru selalu menggunakan media yang ada, hanya saja kalau kami belajar menggunakan media serasa main-main saja. Guru melakukan evaluasi setelah pembelajaran. 


\section{PENUTUP}

Setelah lebih kurang tiga bulan melaksanakan penelitian di SDN Kota Solok, mengamati aktivitas guru, siswa baik ketika belajar atau bermain. Dan juga setelah melakukan beberapa kali wawancara serta melakukan telaah terhadap dokumen yang dimiliki sekolah. Peneliti dapat menyimpulkan beberapa hal penting terkait budaya kerja islam guru-guru SDN Kota Solok dalam meningkatkan mutu hasil belajar. Beberapa kesimpulan peneliti adalah:

1. Gambaran umum budaya kerja islami di SDN Kota Solok sudah melakukan aktivitas-aktivitas yang bernuansa keislaman dan membuat program pembiasaan, seperti mengucapkan salam ketika masuk keluar kelas atau kantor atau ketika bertemu dan berpisah, melaksanakan program-program keagamaan rutin, seperti dhuha, shalat jamaah, penerbitan buku control amalan harian.

2. Budaya kerja islam guru-guru SDN Kota Solok dalam meningkatkan mutu hasil belajar. Penanaman budaya kerja islam guru dilakukan dengan membuat peraturan-peraturan tertulis, untuk guru dan juga untuk siswa. Peraturan untuk guru dibuat oleh instansi pemerintah yang bertujuan untuk menanamkan kedisiplinan kepada guru. Sedangkan peraturan untuk siswa dibuat oleh kepala sekolah bersama-sama dengan siswa di awal semester atau awal tahun ajaran.

3. Budaya kerja islami dilihat dari pelayanan unggul/utama (excellent service) di SDN Kota Solok. Berdasarkan hasil wawancara maka pelayanan pendidikan menjadi sangat penting bagi sekolah sebagai Unit Pelayanan Jasa Pendidikan.Dengan demikian hakekat pelayanan pendidikan tidak hanya berkaitan dengan pemenuhan kebutuhan sarana dan prasarana, perlengkapan dan peralatan belajar yang serba mewah dan canggih, tetapi sangat dibutuhkan iklim dan lingkungan sekolah/belajar yang kondusif, aman, dan menyenangkan

\section{Saran-Saran}

Berdasarkan pengamatan dan wawancara serta kesimpulan yang peneliti dapatkan. Peneliti memberikan saran-saran sebagai berikut:

1. Kepada kepala sekolah agar dapat membuat program sekolah yang secara jelas diberi nama sebagai program pembentukan karakter. Disebutkan jelas apa kegiatannya dan karakter apa yang akan dibentuk melalui program tersebut.

2. Kepada guru SDN Kota Solok diharapkan lebih memberikan penekanan kepada peserta didik untuk mengaplikasikan nilai-nilai karakter yang dimilikinya terhadap siapapun, tidak hanya guru di sekolah, namun juga pegawai di kantor, tamu sekolah dan terutama orang tua atau keluarga di rumah. Sehingga nilainilai baik yang dimiliki tersebut dapat dirasakan manfaatnya oleh siapa saja.

3. Kepada Pimpinan sekolah dan guru agar membuat evaluasi tertulis secara khusus terhadap program penanaman karakter yang telah dilaksanakan. 


\section{KEPUSTAKAAN ACUAN}

Bahauddin M, 2008. Diktat Manajemen Peningkatan Mutu Pendidikan Terpadu, Unmul: Samarinda.

Hafinuddin, Didin. Hendry Tanjung. 2003.

Manajemen syariah dalam praktik, Jakarta:

Gema Insani Press.

Hanafi Halim Abdul. 2010. Metodologi

Penelitian Kependidikan. Batusangkar:

STAIN Batusangkar.

Nanang Fattah, 2003, Konsep Managemen Berbasis Sekolah (MBS) dan Dewan Sekolah, Bandung: Pustaka Bani Quraisy

Nasution, 2005. Manajemen Mutu Terpadu. Bogor: Ghalia Indonesia.

Sudradjat, Hari, Manajemen Peningkatan Mutu Berbasis Sekolah; Peningkatan Mutu Pendidikan Melalui Implementasi KBK, Bandung: Cipta Lekas Garafika, 2005.
Stephen P Robbins, 2006. Perilaku Organisasi, Konsep, Kontroversi dan Aplikasi, Edisi Keenam. Jakarta: Penerbit PT.Bhuana Ilmu Populer.

Tafsir Ibnu Katsir QS.AL-Alaq ayat 1-5.

Taliziduhu Ndraha, 2003. Pengantar teori pengembangan sumber daya manusia, Rineka cipta, Jakarta, anggota IKAPI.

Tjahjadi Bambang, 2001. "Konsep Budaya Organisasi, Kesenjangan Budaya Organisasi dan Pengarubnya terhadap Kinerja Organisasi", Majalah Ekonomi, Th. XI, No.1.

wordpress.com/.../manajemen-sekolahbermutu. 